\title{
Diglossia and Playwriting in Finnish
}

Diglossie et écriture théâtrale en finnois

Diglossia ja näytelmäkirjallisuus Suomessa

\section{Tiina Kaartama}

\section{(2) OpenEdition}

\section{Journals}

Electronic version

URL: https://journals.openedition.org/efo/9293

DOI: $10.4000 /$ efo.9293

ISSN: 2275-1947

\section{Publisher}

INALCO

\section{Electronic reference}

Tiina Kaartama, "Diglossia and Playwriting in Finnish", Études finno-ougriennes [Online], 49-50 | 2018, Online since 28 January 2019, connection on 08 July 2021. URL: http://journals.openedition.org/efo/ 9293 ; DOI: https://doi.org/10.4000/efo.9293

This text was automatically generated on 8 July 2021.

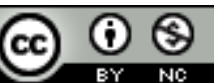

Études finno-ougriennes est mis à disposition selon les termes de la Licence Creative Commons Attribution - Pas d'Utilisation Commerciale 4.0 International. 


\title{
Diglossia and Playwriting in Finnish
}

\author{
Diglossie et écriture théâtrale en finnois \\ Diglossia ja näytelmäkirjallisuus Suomessa
}

Tiina Kaartama

1 There is always a gap to cross when transcribing oral language into writing. This is not just a question of one being produced by a physical body and its voice, and the other being produced by writing transcending the limits of time and space: there is also a linguistic gap, as prevailing norms of good language practices are always somewhat different in written and in spoken speech. The further the standards of the written and the spoken languages are from each other, the more it raises questions, such as how novelists write their dialogues. The question is perhaps even more complicated for playwrights who write texts that are meant to be transcribed into speech. As in Finnish language the standards between written and spoken languages seem rather far from each other, do playwrights take this into consideration? To study this question, the concept of diglossia seems to us a valuable frame.

\section{The Concept of Diglossia}

2 Charles Ferguson described the concept of diglossia as a situation in a speech community where two varieties of the same language are used by the speakers under different conditions (Ferguson, 1959).

3 In research concerning Finland, the concept of diglossia has been widely used to describe bilingualism, such as the Swedish-speaking minority's situation in Finland (Allardt, Miemois, Starsk, 1979), or the position of the English language in Finland. (Hyrkstedt, Kalaja, 1998) Here, however, we are referring to Ferguson's theory as a theoretical frame that considers two co-existing forms of what is commonly considered as only one language. The High standard $(\mathrm{H})$ would be used for instance in literature, in speech in parliament or in news broadcasts, whereas the Low standard (L) would be used for instance in conversations with family, friends or colleagues. 
The difference between a familiar situation of a standard language and its regional dialects would be, according to Ferguson, that in diglossia no segment of the speech community regularly uses what he calls the High standard (H) as a medium of ordinary conversation (Ferguson, 1959, p. 327). This description is highly accurate when observing the situation in Finland.

He also emphasises the fact that only the $\mathrm{L}$ is learned by children in what may be regarded as the "normal" way of learning one's mother tongue, whereas $\mathrm{H}$ is learned through formal education in schools. Again, this is what we can observe in Finland.

\section{Written Finnish and Spoken Finnish}

There are two varieties of language of Finnish language in the sense meant by Ferguson. There is what Finns refer to as kirjakieli, literally translated as "the language of books", or written Finnish, (H) and, on the other hand, there is puhekieli, "the language of speech", or spoken Finnish (L). They are functionally different, and they both have their specific fields of use: one is not normative in a field where the other is to be used. Studies of the relation and the evolution of these two varieties of Finnish are numerous (Hiidenmaa, 2003).

7 The situation is not one in which a national standard would overrule the different regional dialects. The written Finnish $(\mathrm{H})$ does not correspond to the speech of any regional or social language group and thus is not learned, as such, as the mother tongue in any Finnish-speaking community. The child will learn as his or her mother tongue one of the forms of spoken Finnish (L) (Harmanen, 2013, p. 5), whereas written Finnish was originally created to respond to various administrative purposes (Koivisalo, 1986). One can observe geographical and social differences in different forms of this spoken Finnish (L) that do not exist in written Finnish. A child will then learn written Finnish (H), by means of books, usually at school or from the books read by his or her parents. One of the main objectives of schools has been, and is still today, to teach this written Finnish (Koivisalo, 1986; Hamanen, 2013). The question is not solely that of style or vocabulary: there are also grammatical differences between the written Finnish and the spoken Finnish (Hakulinen, 2003).

8 The situations in which one uses one or the other forms are highly codified. The main rule is that the first is written and the second is spoken. Teachers will speak to their pupils or students in spoken Finnish while teaching, but will write the examples on the whiteboard in written Finnish. The pupils will express themselves orally in spoken Finnish but when writing, only written Finnish will be accepted.

9 There are, of course, exceptions: one can hear written Finnish spoken aloud in formal situations. This will be the case for instance in news broadcasts: it is to be noted though that this is an indication to the audience that the information is being read, instead of being thought up on the spot, which gives the necessary credit to the news. In the same way, a lecturer can speak a text aloud written beforehand in written Finnish, but will then discuss its contents with the audience in spoken Finnish. This will be the case also for a political speech: the audience do not expect that the speech is composed spontaneously, and while listening to the written Finnish acknowledges and accepts that whatever the person is saying aloud, has been written beforehand. 
This is changing. Not because the norms of the language have changed, but because the speech culture has changed: where it used to be acceptable or even expected to read a well written speech from notes, the audience might now prefer listening to a speech that seems to be composed spontaneously. This illusion of spontaneous speech is easy to create by expressing oneself in spoken Finnish. Written culture has also changed to some extent. Some new forms of writing, such as e-mails or text-messages, are often written in transcriptions of the spoken language instead of the standard written language. This can be seen as a sign of how these new means of communication are perceived, not yet a major change in language itself (Vinnika, Voutilainen, 2013). And, in any case, a native speaker of Finnish language will immediately recognize one form from the other.

\section{Speech in Novels}

What about if we are writing dialogues? Novelists and playwrights cannot ignore the question. Most Finnish literature is written in written Finnish. However, a novelist can also choose to write a transcription of the spoken Finnish instead of using the normative written Finnish. This is most common when writing dialogues. In the following, we will be referring mainly to the very exhaustive study made by Liisa Tiittula and Pirkko Nuolijärvi on the illusion of speech in novels written in or translated into Finnish (2013).

It is not surprising to note that in dialogues we find very often signs of orality, very often some kind of a transcription of spoken Finnish. One should note however that this transcription is never authentic, as a novelist is creating to eye-sight (written language) an equivalent of what is supposed to be heard (spoken language) (Tiittula, Nuolijärvi, 2013, pp. 27-29). We may also note that this it is not a rule either: many novelists use written Finnish also in dialogues, a tendency that shows no signs of disappearing - on the contrary (Tiittula, Nuolijärvi, 2013, p. 119).

The signs of orality may vary a great deal. One can use means that remain in the field of written Finnish (H). These would be for instance punctuation and exclamations, writing short sentences and repeating words, both typical to dialogues, or hesitations and word order typical to oral expression. Thus all the markers of orality do not belong to spoken Finnish (L). Here, when we speak of written spoken Finnish (L) we are referring to a language that shows phonemic, morphological or lexical signs typical to spoken language. They can be very general (such as using se instead of hän for the third person she/he) or very specific, including detailed signs permitting to identify a specific regional dialect. At first sight, there seems to be a rather big grey area where the two coincide and there is a real theoretical difficulty to define the limit between $\mathrm{L}$ and $\mathrm{H}$ (Hiidenmaa, 2003, pp. 231-233). However, a Finnish teacher is rarely puzzled in front of a pupil's work: he or she will correct with no hesitation all forms of spoken Finnish when found.

14 If an author chooses to use spoken Finnish in dialogues, it will be very difficult to do so without including in the language some information on the characters, such as their age or social position. This information will be understood indirectly. Rare and only general signs of spoken Finnish will create a simple illusion of speech, reinforcing the idea of a bond between the story in the book and the reality. However, the more the signs become specific, the more the author seems to highlight the specific nature of the 
character. Interestingly, the further the speaker is from whatever is the standard, whether a child, a teenager, an old, homeless or non-educated person, a foreigner or a criminal, the more likely it is that his or her speech will be written in a transcription of the spoken Finnish (Tiittula, Nuolijärvi, 2013, pp. 233-234). Thus one can argue that if spoken Finnish certainly reinforces the realism of the dialogue in general, it can also efficiently create a distance between a particular character speaking and the reader.

This is particularly true in popular fiction and in detective stories. Popular fiction and most detective stories rarely question the social norms, on the contrary, they give to the reader quite stereotyped representations of these norms. According to Juhani Niemi, popular fiction follows simple themes, ordinary narrative structures and a standard worldview (Tiittula, Nuolijärvi, 2013, p. 156). In this kind of literature, the language in dialogues will often be a marker of the social status of the speaker: the "bad guy", let's say a burglar, will express himself in spoken Finnish, where as the "good guy's" language, let's say the policeman's language, will be written in written Finnish, especially if on duty. (Tiittula, Nuolijärvi, 2013, p. 185) We should note that this differentiation does not reflect a reality: in real life the policeman and the burglar would both speak spoken Finnish one to another, probably different levels or different types of spoken Finnish, but definitely spoken Finnish. And probably both of them would write down a report or a statement in written Finnish, and then a text-message in a transcription of the spoken Finnish to their wives or partners to tell them not to wait for dinner. Here, the representation of the language in literature does not reflect the reality, but the idea we make of it: written Finnish is considered high-standard and "better", and thus the "good guys", the ones the reader are supposed to want to identify with, ideally speak written Finnish, whereas spoken Finnish is low-standard and associated for instance with a lack of education (Hiidenmaa, 2003, p. 238). As Ferguson points it out:

"Speakers regard H as superior to L in number of respects." (Ferguson, 1959, p. 329)

A novelist can choose to use a transcription of spoken Finnish also in narrative parts. This has become more and more frequent in literature since the 90's (Tiittula, Nuolijärvi, 2013, p. 113). However, the inherent orality of the spoken Finnish does not fade nor disappear from the language. Using spoken Finnish will introduce this orality to the experience of the reader and will create the illusion of an inner monologue or that of a story been told by an individual narrator in a face-to-face situation (Tiittula, Nuolijärvi, 2013).

We can conclude that, in novels, the act of writing will set the norm to the artistic expression: while writing, using written Finnish is the prevailing norm. A reader expects to read written Finnish(H), and thus using spoken Finnish(L) can be considered as exceptional. In narrative parts, using spoken Finnish is rare, and when this is done, it will introduce a particular, personal point of view to the narrative act. In dialogues, transcriptions of the spoken Finnish are often used for the sake of realism. The more the literary gender reinforces the prevailing social norm, such as popular fiction, the more likely the book will be written solely in written Finnish (H), even in dialogues, thus respecting the linguistic code and its ideals. Moreover, in most literary genders, the higher the character's social position, the more likely his or her speech will be written in written Finnish $(\mathrm{H})$. The written Finnish is thus what often reinforces in novels both the linguistic norm $\mathrm{H}$ and the social norm regarding to the supposed - but often imaginary - uses of $\mathrm{H}$. 


\section{Playwrights Write Speech}

Playwrights are in a different situation. A playwright writes a text that is not meant to be read, but to be spoken on stage, and not only to be spoken but also to be heard. In novels, written Finnish is by no means an obstacle for realism, as written Finnish corresponds to the expectations of the reader. On stage, however, hearing written Finnish would be highly awkward and would interfere with the illusion of creating the speech spontaneously.

In a novel the interface between the writer and the reader is the book (or screen), which permits a distance in time and in space. The reader freely controls when and where he or she chooses to read the book. There is a distance between the writer and the book, and again between the book and the reader, which corresponds to the distance with written Finnish. On stage, the interface is the speaking actor, which puts the writing and the audience in the same space and in a limited time span. The written play takes form through the actors and the audience, and even though everybody (meaning here the audience) is not speaking - which is not the case in conversational situations either - the presence of everybody is required for the play to exist. This corresponds more to a classical situation of a face-to-face communication in which typically spoken Finnish is used.

Indeed, we can observe that contemporary Finnish playwrights mainly use different transcriptions of spoken Finnish in their plays. The norm is clearly reversed when compared to novelists. As mentioned above, in public speaking one can create the illusion of a spontaneously created speech by expressing oneself in spoken Finnish no matter whether the speech has been written beforehand or not. Playwrights will nearly systematically use this opportunity for their art. For this article, we have chosen to study plays from Juha Jokela, Emmi Karhu, Okko Leo, Pirkko Saisio, Sirkku Peltola and Milja Sarkola as they represent a wide range of artistic and linguistic propositions as well as different positions in the professional field. All were interviewed in 2017.

\section{General case: Dialogues Are Written in Spoken Finnish and Stage Directions in Written Finnish}

21 Juha Jokela is looking in the dialogues for a truly realistic phonetic transcription of a Helsinki-based speaker, reflecting very authentically actually existing professional jargon and contemporary popular expressions. There are few stage directions and they are systematically written in written Finnish. An example of the way he uses language would be the following line of Seppo, from Mobile Horror:

“Seppo (oivaltaa): Aivan... No mut niinhän se kannattaa tehdä! Pantataan vähän ja sit kun tuote imee, ni meillonkin lyödä, vähän niinkun puun takaa splät, et hei, meilläpä on tällanenkin kortti. Onks sul sit meidän tuotepolitiikasta, niin onks sulla mitään ideaa?"

"Seppo (gets the idea): Right... Yeah but this is exactly the way we need to do it! Let's hold this for a while and when the stuff gets hot, then we can, you know, like from behind a tree ta-da!, like hey, look at this card we have! So do you have any, you know about our product policy, any ideas?

The short stage direction is in written Finnish, whereas the line uses several phonetic transcriptions from spoken Finnish (mut, sit, meillonkin, niinkun, et, tällanenkin, onks sul,

Études finno-ougriennes, 49-50 | 2018 
onks sulla), short (spoken) forms of personal pronouns (sul, meill, sulla), as well as a great variety of forms typical to speech such as uncomplete structures (pantataan vähän, no object, meillonkin lyödä, no object, onks sul sit meidän tuotepolitiikasta, no object), filled pauses (aivan, niin onks sulla), specific vocabulary and expressions (tuote imee), onomatopoeia (splät), and sentences changing direction and structure while being created by the speaker (meillonkin lyödä [...] meilläpä on tällanenkin kortti).

Juha Jokela aims, to quote his own words, "to create an authentic speech, that sounds like real speech, [...], and that the characters have their own way of speaking". His plays take place in realistic situations with characters one can identify. Thus, using written Finnish in dialogues would have no purpose.

Pirkko Saisio uses the same major frames in her plays: the very few existing stage directions are in written Finnish and the dialogues are either transcriptions of spoken Finnish, or create a sufficient illusion of it to the audience. Most of her plays could be classified as realistic ones in the sense that their characters evolve in a recognizable way. However, authenticity of speech is not her aim. For Saisio, a stage language should not follow the rules of authentic speech: it should be more compact and meaningful. Interestingly, we can observe in her plays different levels of speech reflecting the characters' social position: the higher the position, the less there are signs of regional dialects or vocabulary specific to speech. If plays would follow the same general schemes as novels, we could thus expect that the characters having a fairly high social position (politicians, doctors, etc.) would express themselves in written Finnish (Tiittula, Nuolijärvi, 2013, p. 230). This is not the case, however: significantly, this line is never crossed. Even if vocabulary specific to speech is often lacking in their lines, they still contain other major signs of spoken Finnish, such as short forms of pronouns, adverbs and past participles. In the following excerpt, Seppo is a lawyer with an international career in Brussels, and Milva is a young photographer, also Seppo's daughter-in-law. The spoken forms are in bold, missing parts are marked with a $\mathbf{0}$, and incomplete sentences are indicated in italics:

Seppo: Miksi sä haluat katsoa mua?

Seppo: Why do you want to look at me?

Milva: Vaihtelun vuoks0. Mua on katsottu niin paljon, että $\mathbf{0}$ on ruvennu0 kyllästyttämään.

Milva: For a change.People have looked at me so much it gets boring.

Seppo: Sulla on aika isot luulot ittestäsi, tyttö.

Seppo: You think quite big about yourself, girl!

Milva: Niin on. Hyvin mitootetut. Realistiset."

Milva: Yep. One size, fits me.

As we can see, both characters use spoken forms, but Seppo forms full sentences, whereas Milva completes the meaning of her sentences as her thoughts advance. This is very typical, not only to speech in general (Tiittula, Nuolijärvi, 2013), but to several of Saisio's plays. Here the structures of speech highlight the difference between an older character taking time to form his thoughts before expressing them, and a younger person speaking more spontaneously.

\section{A specific Case: Using Written Finnish in Dialogues}

Sirkku Peltola writes her plays mostly in spoken Finnish, with particularly accurate transcriptions of dialectal speech. She does not always follow the rule "dialogue in spoken, stage direction in written Finnish". Spoken Finnish can be found 
occasionally also in stage directions, as if they would carry on, in silence, a character's speech. Sometimes we can observe some written Finnish in dialogues: it can be used when the characters are making an effort in a public situation or when they find themselves otherwise in an uncomfortable situation. In the following, Aili is accusing her former husband Lassi of their soon-to-come bankruptcy:

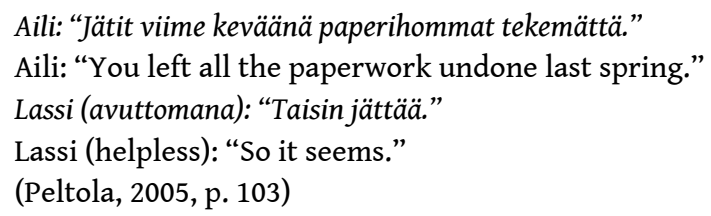

The moment is one of the key-moments of the play: Aili - and the audience - has been aware of this situation, explaining most of the action of the play, since a while without Lassi himself knowing it. The two lines are exceptionally in written Finnish, stressing on their declamatory, non-negotiable character. Written Finnish is thus again associated to speech that does not reflect the character's "authentic", spontaneous nature.

Written Finnish can be used also when the characters are speaking directly to the audience, typically in monologues. It denotes thus a different functional level of language. In the same way, it is systematically used when characters are citing literature or a proverb, or when something is being read. In these cases there is no need to add quotes or stage directions such as "reads from a note", "stops reading" as this is present in the nature of language. Hearing written Finnish will indicate to the audience that these words are not the character's own words.

Sometimes also in Pirkko Saisio's plays the characters will express themselves exceptionally in written Finnish. It is interesting to notice that this will be the case when the characters are playing a role themselves, pretending to be somebody they are not: an author pretending to be a policeman, or a woman playing a fictional role in erotic games.

In some of Sirkku Peltola's plays we can also find characters who use mainly written Finnish in their lines. This, however, is an indication to the audience that the character feels him or herself uncomfortable in life in general and lacks spontaneity. Thus, hearing written Finnish spoken aloud is a sign to the audience that something non-real, non-authentic, non-spontaneous is taking place on stage.

Milja Sarkola is a Swedish-speaking Finnish writer, writing plays both in Swedish and in Finnish. Her relationship to Finnish language is less confident than the other writers', as it is not her mother tongue. After having written a play, she does what she calls "a cleaning-up". This means that she makes sure that the different levels of the language are coherent. Her plays don't always include classical characters, in the sense that one actor would interpret one character evolving throughout the whole play. She says that she distributes the lines sometimes only after having written the whole and some parts might even be interpreted as choral works. Characters are very often also narrators, speaking directly to the audience in present time and place, commenting on events taking place on stage or how they feel about them. These parts are quite systematically in written Finnish, whereas the dialogues which take place on what is defined as the stage - the place where fiction becomes a separate reality regarding to time, space and other imaginary possibilities - are mostly written in spoken Finnish. 
This means that the two different languages, $\mathrm{H}$ and $\mathrm{L}$, are again used in two functionally different purposes. These roles are not the same ones as in the general case, but some convergence can be noticed. In the fictional, separate reality of the stage, the language will be what the audience can recognize as the general way of speaking (spoken Finnish, L). When the character steps out of this separate reality and speaks directly to the "real-life" audience, he or she will use the written Finnish, H. Even if at first glance this seems to be in contradiction with the standards, the explanation seems evident: when speaking to the audience, the actor is not having a dialogue with it, as the latter is not expected to reply. Thus it is not a standard use of speech, but more a way of taking the audience as a witness to ones words. Using written Finnish makes clear that no answer is expected and thus insures the theatrality of the speech. Written Finnish implies that the words are not spontaneous, and as such whatever is said to the audience, remains in the realm of acting.

\section{Another Specific Case: Exploring the Limits of a Stage Language}

Emmi Karhu differs from the previous writers as she uses mostly written Finnish in her plays. When spoken Finnish occurs, it happens mostly in occasional vocabulary, and only rarely in morphological structures or phonemic signs. This creates a distance between the audience and the play: the stage and the audience are evolving clearly in different spaces, and characters are merely figures, signs, archetypes, all but fresh and blood. Interestingly, when interviewed, Emmi Karhu says that she doesn't specifically write plays:

"I start writing, and so far it has just happened so that it ends up by been a play."

In that way, she might be considered, not as a playwright nor a novelist, but a writer of fiction. The layout follows the conventions of drama: there are scenes, stage directions and dialogues, but the language, when it comes to written/spoken Finnish, follows the general rules of novels: written Finnish is the norm, whereas spoken Finnish will indicate something out of norm. In novels, written Finnish meets the expectations of the readers and permits a wide range of styles, even realism or inner monologues. But on stage, spoken out loud, the language changes status. As written Finnish will sound awkward, the audience will not expect any realism. This distance can obviously be highlighted in many ways by directors.

Another atypical playwright is Okko Leo, whose work questions the limits of the stage language. The plays are very different one from each other regarding how the language is used. Nevertheless, we can find some constant themes: the further the play is from a realistic everyday life, such as a futuristic story, or the further it is from the prevailing norms of how a play should typographically look like, the more it will contain written Finnish. The more the plays are traditional with constant characters or an intrigue advancing in time, the more it will contain spoken Finnish. This doesn't mean, however, that the language would remain unquestioned. The transcription of the orality might be very different from the prevailing norms. In the following we can appreciate Okko Leo's transcription compared to a more standard one:

Antero: JOSME oltas maalla ni SOLIS ihan ookoo.

Antero: JOS ME oltas maalla ni SE OLIS ihan ookoo.

Antero : If we were in the countryside, that'd be OK. 
, the transcribed units follow rather a musicality instead of the standard semantical or grammatical separations: JOS (conjunction "if") ME (subject "we") becomes JOSME, and SE (subject "it") OLIS (verb "would") becomes SOLIS. The stage directions - sometimes in spoken Finnish - might also become a voice of a separate character, in dialogue with what he/she/it is observing and questioning it, rather than simply describing acts to be done or seen. The different functions of the written and spoken languages are thus a supplementary tool for the author when questioning the limits of playwriting.

\section{In Conclusion}

We can thus observe that playwrights implicitly confirm, with their practices, the existence of the situation of diglossia in the sense meant by Charles Ferguson. The functional differences of spoken and written Finnish are systematically found in plays. Occurrences of written Finnish (H) correspond merely to non-spontaneous speech situations such as distanciated forms of expression, monologues, fake characters or reading aloud, whereas spoken Finnish (L) is used in dialogues corresponding to standard speech situations regardless of the social position of the speaker.

This is even more evident as several playwrights insist spontaneously in the interviews that using spoken Finnish does not mean using a simplified language. It is clear to them that spoken Finnish is not a simplified version of a colloquial language, nor an impoverishment, but a truly expressive language with all the necessary colours and shades which gives the writer all possibilities of expression, even the very condensed ones required in stage language limited in time and space. Thus the difference of the two languages is not a value based appreciation on a better-worse-scale, but the difference is very clearly a functional one. As characters evolve on stage expressing themselves with speech, it is thus natural for them to use spoken language.

\section{BIBLIOGRAPHY}

ALLARDT Erik, MIEMOIS Karl Johan \& STARCK Christian, 1979, Multiple and varying criteria for membership in a linguistic minority: the case of the Swedish speaking minority in metropolitan Helsinki, University of Helsinki (coll. Research reports, Research Group for Comparative Sociology), Helsinki, 97 p.

FERGUSON Charles A., 1959, "Diglossia” in Word, n² 2, vol. 15, pp. 325-340, DOI :

10.1080/00437956.1959.11659702.

HAKULINEN Auli, 2003, « Vielä nykysuomesta ja sen huollosta. Ovatko puhuttu ja kirjoitettu kieli erkaantuneet toisistaan?» in Kielikello kielenhuollon tiedotuslehti.

Kieliverkosto, 2013, « Kieli ja tekstitietoisuutta kouluun! Kielitietoinen koulu ja äidinkielen ja kirjallisuuden opetus », Minna Harmanen En ligne, https://www.kieliverkosto.fi/fi/journals/

Études finno-ougriennes, 49-50 | 2018 
kieli-koulutus-ja-yhteiskunta-joulukuu-2013/kieli-ja-tekstitietoisuutta-kouluun-kielitietoinenkoulu-ja-aidinkielen-ja-kirjallisuuden-opetus.

Kielikello kielenhuollon tiedotuslehti, 1985, « Miten normikieltä varten annetut suositukset ja ohjeet on tulkittava? », Esko Koivusalo, https://www.kielikello.fi/-/miten-normikielta-vartenannetut-suositukset-ja-ohjeet-on-tulkittava- (consulté le 6 novembre 2017).

Kielikello kielenhuollon tiedotuslehti, 1986, « Mitkä ryhmät yhteiskunnassa ovat puhuneet tähän saakka kirjakieltä?», Esko Koivusalo, https://www.kielikello.fi/-/mitka-ryhmat-yhteiskunnassaovat-puhuneet-tahan-saakka-kirjakielta- (consulté le 6 novembre 2017).

Kielikello kielenhuollon tiedotuslehti, 2013, « Ääniä ilmassa, merkkejä paperilla puhutun ja kirjoitetun kielen suhteesta », Jenni Viinikka \& Eero Voutilainen https://www.kielikello.fi/-/ aania-ilmassa-merkkeja-paperilla-puhutun-ja-kirjoitetun-kielen-suhteesta (consulté le 5 octobre 2017).

HIIDENMAA Pirjo, 2003, Suomen kieli, who cares?, Otava, Helsinki, 317 p.

HYRKSTEDT Irene \& KALAJA Paula, 1998, “Attitudes toward English and Its Functions in Finland: A Discourse-Analytic Study” in World Englishes, $n^{\circ}$ 3, vol. 17, pp. 345-357, DOI : 10.1111/1467-971X. 00108.

TIITTULA Liisa \& NUOLIJ̈RVI Pirkko, 2013, Puheen illuusio suomenkielisessä kaunokirjallisuudessa, Suomalaisen Kirjallisuuden Seura (coll. Suomalaisen Kirjallisuuden Seuran toimituksia), Helsinki, $637 \mathrm{p}$.

\section{Corpus}

JOKELA Juha, 2003, Mobile horror: näytelmä, WSOY, Helsinki, 102 p.

JOKELA Juha, 11.02.2017, « Interview ».

KARHU Emmy, 2016, Prinsessa Hamlet ja muita näytelmiä, Into, Helsinki, 272 p.

KARHU Emmy, 18.02.2017, « Interview ».

LEO Okko, 2006, Kenttä, [play].

LEO Okko, 2007, Nimeni on rakkaus, [play].

LEO Okko, 2010, Maailma luottaa meihin, [play].

LEO Okko, 2013, Orkesteri - The Everlast, [play].

LEO Okko, 17.08.2017, « Interview ».

PELTOLA Sirkku, 1996, Muovikassissa kaikki.

PELTOLA Sirkku, 2005, Suomen hevonen: näytelmä, Aamulehti, Tampere.

PELTOLA Sirkku, 18.02.2017, « Interview ».

SAISIO Pirkko, 11.02.2017, « Interview ».

SAISIO Pirkko, 1978, Maailman laidalla, [play].

SAISIo Pirkko, 1994, Ihana ihminen, [play].

SAISIo Pirkko, 2003, Tunnottomuus,[play].

SARKoLA Milja, 2011, Perheenjäsen, [play]. 
SARKOLA Milja, 17.02.2017, « Interview ».

\section{ABSTRACTS}

The concept of diglossia, as presented by Ferguson in 1959, is an interesting framework to study the variations between written and spoken language in Finnish. Diglossia is a situation in a speech community where two varieties of the same language are used by the speakers under different conditions. Only one of the varieties is learned by children in what may be regarded as the "normal" way of learning one's mother tongue, whereas the other is learned through formal education in schools. This functional differentiation can be distinguished in the Finnish language. in literature, the differentiation can be observed in differences between narration (written Finnish) and dialogues (spoken Finnish). in theatre plays the norms change, as the text is written in order to be spoken aloud. Most of the plays are written in spoken Finnish, except for the stage directions, which are not meant for the audience. If a character uses written Finnish in a dialogue, it is an indication for the audience that the situation is not that of a "spontaneous" dialogue: it can be a monologue, or the character is reciting something or pretending to be someone else. Thus, the different functions of written and spoken Finnish observed in theatre plays reinforce the prevailing functional differences and diglossia.

Le concept de diglossie, présentée par Ferguson en 1959, est un cadre intéressant pour étudier les variations entre le finnois standard (ou écrit) et le finnois parlé. Dans la diglossie, on peut observer, dans une même communauté linguistique, deux variétés de langue qui sont utilisées dans des contextes différents. Une de ces langues est apprise par ce qui pourrait être considéré comme la voie «normale » d'apprentissage de la langue maternelle, l'autre par l'enseignement formel à l'école. Cette différence fonctionnelle est assez claire en finnois. Dans les œuvres littéraires, la différence s'observe dans les langues utilisées dans la narration (finnois standard) et dans les dialogues (finnois parlé). Dans les pièces de théâtre, la norme est inversée, puisque les textes sont écrits en vue d'être dits. La plupart des pièces sont écrites en finnois parlé, excepté les didascalies qui ne sont pas destinées au spectateur. Lorsqu'un personnage s'exprime en finnois standard, le spectateur peut deviner qu'il ne s'agit pas d'un dialogue "spontané », mais par exemple d'un monologue, d'une citation, ou encore d'un personnage qui prétend être ce qu'il n'est pas. Ainsi, les différents usages du finnois standard et du finnois parlé dans les pièces de théâtre renforcent les différences fonctionnelles de ces deux variétés et la diglossie.

Fergusonin vuonna 1959 esittelemä diglossian konsepti antaa kiinnostavan mallin suomen kirjakielen ja puhekielen välisten variaatioiden tutkimiseen. Fergusonin mukaan joissain kieliyhteisöissä voidaan havaita kaksi variaatiota, joiden käyttöalueet ovat selvästi eriytyneet ja joista toinen opitaan äidinkielenä (puhekieli) ja toinen yleensä koulussa (kirjakieli). Puhe- ja kirjakielen funktionaalinen eriytyminen on suomen kielessä melko selkeä. Kaunokirjallisuudessa tämä eriytyminen voidaan havaita eri kielinä kerronnassa (kirjakieli) ja dialogeissa (puhekieli). Näytelmäkirjallisuuudessa kielen normit muuttuvat, sillä kirjoitettu teksti on tarkoitettu puhuttavaksi. Voidaankin havaita, että näytelmistä valtaosa on kirjoitettu puhekielellä, lukuunottamatta näyttämöohjeita, joita ei yleensä ole tarkoitettu yleisölle. Jos henkilöhahmo käyttää puhuessaan kirjakieltä, se on viesti katsojalle siitä, että tapahtuu jotain tavallisesta vuoropuhelusta poikkeavaa: kyseessä voi olla monologi, tai henkilöhahmo esimerkiksi siteeraa jotain tai jotakuta tai teeskentelee olevansa joku muu. Näytelmäkirjallisuudessa havaitut puhe- ja kirjakielen eri funktiot ovat siis omiaan vahvistamaan olemassa olevia käytäntöjä ja kielen kahtiajakoa. 


\section{INDEX}

Mots-clés: études théâtrales, études théâtrales, auteur dramatique, auteur dramatique, dialogue, dialogue, diglossie, diglossie, discours écrit, discours écrit, drame, drame, écriture dramatique, écriture dramatique, langue écrite, langue écrite, langue orale, langue orale, narration, narration, Finnois, Finnois, Suédois, Suédois, anglais, anglais, finnois, finnois, suédois, suédois, XXIe siècle début, XXIe siècle début, Finlande, Finlande motscleset teatriuuringud, dialoog, diglossia, draama, kirjakeel, näitekirjanik, suuline keel, teater, rootslased, soomlased, inglise, rootsi, some, 21. sajand algus, Soome Keywords: theatre studies, dialogue, diglossia, drama, oral language, playwriting, playwright, theater, theatre, written language, written speech, Finns, Swedes, English, Finnish, Swedish, 21st century beginning, Finland 